\title{
Subject Choice Information as a Component of Career Guidance: It's Status in Secondary Schools in Uriri Sub-County, Kenya
}

\author{
Ongang’a P. Odhiambo \\ Lecturer, Kabarak University, Nakuru, Kenya

\section{Article History} \\ Received: 16.07.2020 \\ Accepted: 04.08.2020 \\ Published: 24.10 .2020 \\ Journal homepage: \\ https://www.easpublisher.com/easjehl

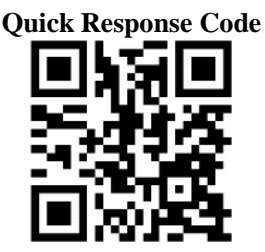 \\ Abstract: In Kenya, the subjects that students choose in secondary schools greatly \\ determine their career paths. This is because the subjects done at secondary schools dictate \\ the courses they do at the post-secondary level of training. Studies show that majority of \\ students are not aware of their career choices while in secondary schools hence they find \\ themselves in the subjects they do either accidentally, or by being greatly influenced by \\ other external factors other than career awareness. It is therefore paramount that subject \\ choice guidance to students, if incorporated in career guidance programme to a great extent \\ can help to solve the problems of students landing in wrong careers because they did not \\ choose the right subjects while in secondary schools. This study sought to determine the \\ extent to which the subject choice is incorporated in to career guidance programmes in \\ secondary schools in Uriri Sub-County. The study employed ex-post facto research design. \\ The target population in the study was 262 form three Agriculture students. 152 Agriculture \\ students were drawn by proportionate stratified random sampling. A closed ended \\ questionnaire was used to collect data. Data was analysed using SPSS package version 22 \\ and presented and analysed using frequencies, percentages, means and standard deviations. \\ The study found out that information on subject choice was available to a large extent, \\ sufficient to help secondary school students in Uriri Sub-County to make informed career \\ choices. \\ Keywords: subject choice, agriculture, career guidance, secondary schools.
}

Copyright ( $) 2020$ The Author(s): This is an open-access article distributed under the terms of the Creative Commons Attribution 4.0 International License (CC BY-NC 4.0) which permits unrestricted use, distribution, and reproduction in any medium for non-commercial use provided the original author and source are credited.

\section{INTRODUCTION}

Career choice is an integral part of any society, a process that begins at school and culminates into placement at the end of training. It has become a complex science especially with the advent of information technology, leading to unprecedented job competition [1]. Before the advent of information technology, it was possible for one to accumulate riches so long as he had landed a job. Today, individuals have to make wise career decisions if they are to live a worthy life thereafter. Majority of students in Kenyan secondary schools do not have adequate information on career choice [2].

A study by Gicharu, [3] revealed that students were particularly keen about their perceptions of areas of study and were not certain about what Agriculturerelated careers are due to little information. Hansel [4] however argues that students enrol for agricultural courses because they have certain degree of preference for Agriculture-related careers. In the Kenyan context, students may be admitted to universities to take Agriculture-related courses irrespective of whether they took it in secondary schools.
In addressing the issues underlying career awareness, schools are the key players to ensure that students receive adequate career information in relevance with their subject combinations so as to find it easy to fit in training at higher levels. Secondary schools in Kenya have a vibrant guidance and counselling programme [5]. Any guidance and counselling programme cannot be complete without matters subject-choice incorporated. In majority of schools in the sub-county, career programmes are amalgamated in guidance and counselling due to insufficiency of man-power leading to multi-tasking by teachers.

A study by Ongang'a [6] showed that majority of students were provided with career information in schools. The study also noted that the career information provided was sufficient for students to help them make career decisions at the present time. It also found out that most secondary school students make their career decisions while at school and that when they join higher learning institutions they are well prepared for the kind of training offered there. 
Learning experiences have been reported to have a high influence on career choice by secondary school students in Kenya. Leaning experience in this respect refers to the scenario where students have good exposure to the range of subjects they have in schools and their impacts on careers. In schools where teachers do not take about subject choices, students will mostly find themselves landing in careers irrelevant to the subjects they had studied. This leads to mismatch of skills and abilities and even interest in Kenyan universities and colleges.

From the above experiences, it is therefore fundamental to provide a means through which subject choice information can be incorporated into career guidance in schools.

\section{Purpose of the Study}

The purpose of this study was to describe the status of subject choice information as a component of career guidance in secondary schools in uriri subcounty, Kenya.

\section{Objectives of the Study}

The objectives of the study were:

i. To describe the demographic characteristics of secondary school students in uriri sub-county.

ii. To find out the status of subject choice information as a component of career guidance in secondary schools in uriri sub-county.

\section{METHODOLOGY \\ Research Design}

The study adopted the ex-post facto research design. The design was more suitable for this study because the researcher sought to find out the subject's already established opinions regarding the research objectives [7]. The respondents were studied after the choice of study subjects had been done and also after career guidance had taken place.

\section{Research Environment}

The study was conducted in Uriri Sub-County of Migori County. The Sub-County is bordered by Awendo Sub-County to the East, Suna East Sub-County to the South, Nyatike Sub-County to the West and Ndhiwa Sub-County to the North. The Sub-County is of high agricultural potential. Majority of people here are tobacco and sugarcane farmers, through which they are able to send their children to school. Because the majority of parents here are agriculturalists, and most students in these schools come from within the SubCounty, it means that most of the students have some background in Agriculture. It is also worth mentioning that majority of schools here are mixed/co-educational day and boarding. The Sub-County has seven-teen secondary schools. It also has various categories of schools i.e. mixed/co-educational schools and single gender schools, therefore making it suitable for the study.

\section{RESEARCH METHODS}

Proportionate stratified random sampling was used in this study to get the number of students in each school category among the 17 schools. A formula by Kathuri and Pals [8] was used to obtain the number of members from each stratum (school type) which was arrived at as follows:

$\mathrm{n}_{i}=\mathrm{N}_{i} / \mathrm{N} * \mathrm{n}$

Where;

$\mathrm{n}_{i}=$ Number of members in the sample from stratum $i$

$\mathrm{N}_{i}=$ Number of members in the population from stratum $i$

$\mathrm{N}=$ Number of members in the entire population

$\mathrm{n}=$ Sample size

$\mathrm{i}=1,2,3$ schools types

Table-I: Sample of students included in the study from different categories of schools

\begin{tabular}{|c|c|c|c|c|}
\hline School type & $\begin{array}{c}\text { Number of } \\
\text { schools }\end{array}$ & $\begin{array}{c}\text { Number of } \\
\text { Schools } \\
\text { Sampled }\end{array}$ & $\begin{array}{c}\text { Total Agriculture } \\
\text { students }\end{array}$ & $\begin{array}{c}\text { Sample } \\
\text { size }\end{array}$ \\
\hline Boys' & 2 & 1 & 60 & 33 \\
\hline Girls' & 2 & 1 & 32 & 18 \\
\hline Mixed/Co-educational & 13 & 5 & 170 & 101 \\
\hline Total & 17 & 7 & 262 & 152 \\
\hline
\end{tabular}

From the seven-teen schools in the SubCounty, only seven were picked by simple random sampling to provide the sample for this study.

\section{Instrumentation}

A questionnaire consisting of two sections was used to acquire relevant information from the respondents. The questionnaire was constructed using Likert scale. Closed-ended items were used. The questionnaire collected information on the following areas:
I. Demographic characteristics of secondary school students.

II. Status of subject choice information in secondary schools in uriri sub-county.

\section{DATA ANALYSIS}

The collected data was first cleaned up for any errors such as incompleteness or inaccurate marking of responses. Data was then coded and recorded to reduce mass for ease of analysis. Data was then entered into the computer for analysis using Statistical Packages for 
Social Sciences Version 22. Descriptive statistics was used in describing nominal data for this study. Data was further analysed and presented using measures of central tendency i.e. means and percentages where appropriate.

\section{RESULTS AND DISCUSSION}

\section{Demographic Information of the Respondents}

Objective one sought to find the demographics of the students. The study randomly sampled 152 Agriculture students from the three school types. The school types as mentioned earlier are: boys' girls' and mixed or co-educational.

\section{Respondents' School}

The study was conducted in seven schools out of the seventeen available in the Uriri Sub-County.

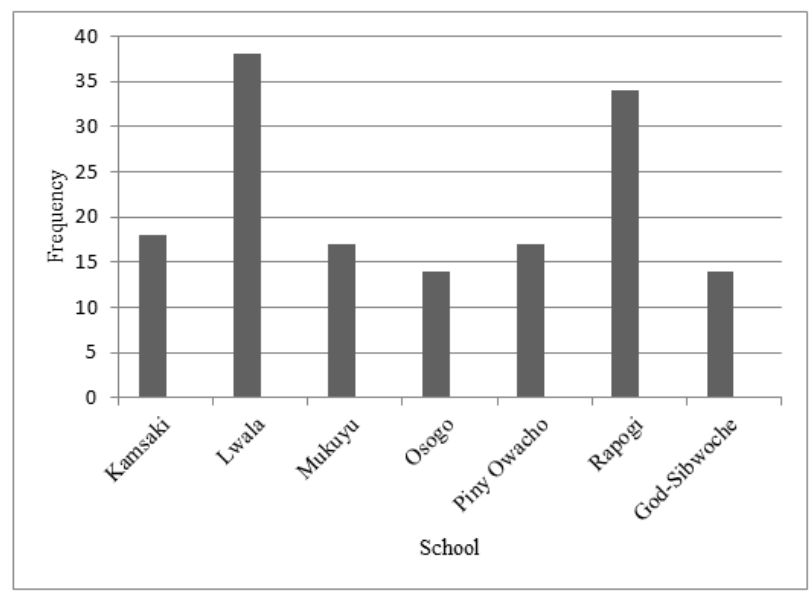

Fig-1: Number of respondents sampled per school

\section{Distribution of Respondents by School Types}

The school types categorised into boys' girls and mixed/co-educational were investigated so as to provide information on the distribution of respondents. The categories of schools are shown in Table 4.

Table-II: Type of school from which sampling was done $(\mathrm{N}=152)$

\begin{tabular}{|c|c|c|}
\hline School type & Frequency & Percent \\
\hline Boys' & 33 & 21.7 \\
\hline Girls' & 18 & 11.8 \\
\hline Mixed/Co-educational & 101 & 66.4 \\
\hline Total & 152 & 100 \\
\hline
\end{tabular}

Though the respondents were sampled from different school categories, most $(66.4 \%)$ were from mixed/co-educational schools. On the other hand, 21.7 percent were from boys' and 11.8 percent from girls' schools. Since most schools in the Sub-County are mixed/co-educational, it was apparent that majority of the respondents were derived from those schools through proportionate stratified random sampling.

\section{Distribution of Respondents by Gender}

The Sub-County has the three school categories as earlier mentioned where boys and girls are distributed. Table 5 gives the summary distribution of the respondents by gender.

Table-III: Respondents' gender $(\mathbf{N}=152)$
\begin{tabular}{|l|l|l|}
\hline Gender & Frequency & Percent \\
\hline Male & 103 & 67.8 \\
\hline Female & 49 & 32.2 \\
\hline Total & 152 & 100 \\
\hline
\end{tabular}

The results show that the majority $(67.8 \%)$, of the respondents were males. This could be interpreted to mean that more boys than girls have chosen Agriculture as one of their subjects of study. Gender of the respondents was considered in this study because based on this, boys and girls may be presented with different opportunities as far as the choice of Agriculture subject is concerned. A study by Owoyele and Toyobo [9] revealed that more boys than girls would register for Agriculture because the subject is considered more masculine hence more boys than girls would register for it based on this perception.

\section{Status of subject choice information}

In objective two, the study sought to provide descriptive information on the availability of subject choice information to the respondents. This information was important because it provided the impetus on the level of subject choice information the respondents had.

In the study, the researcher sought to find out if the respondents are provided with information on subject choice. Table 6 shows the distribution of the respondents according to availability of information on subject choice and the sufficiency of the information provided.

Table-IV: Provision of subject choice information to respondents $(n=152)$

\begin{tabular}{|c|c|c|c|c|c|c|c|c|c|c|c|c|}
\hline \multirow{3}{*}{ Question } & \multicolumn{10}{|c|}{ Option } & \multirow{2}{*}{\multicolumn{2}{|c|}{ Total }} \\
\hline & \multicolumn{2}{|c|}{$\begin{array}{l}\text { Strongly } \\
\text { disagree }\end{array}$} & \multicolumn{2}{|c|}{ Disagree } & \multicolumn{2}{|c|}{ Not sure } & \multicolumn{2}{|c|}{ Agree } & \multicolumn{2}{|c|}{$\begin{array}{l}\text { Strongly } \\
\text { agree }\end{array}$} & & \\
\hline & $\mathrm{f}$ & $\%$ & $\mathrm{f}$ & $\%$ & $\mathrm{f}$ & $\%$ & $\mathrm{f}$ & $\%$ & $\mathrm{f}$ & $\%$ & f & $\%$ \\
\hline $\begin{array}{l}\text { Provision of subject choice } \\
\text { information to respondents }\end{array}$ & 3 & 2.0 & 4 & 2.6 & 1 & 0.7 & 78 & 51.3 & 66 & 43.4 & 152 & 100 \\
\hline $\begin{array}{l}\text { Sufficiency of subject choice } \\
\text { information }\end{array}$ & 6 & 3.9 & 13 & 8.6 & 3 & 2.0 & 66 & 43.8 & 63 & 41.7 & 152 & 100 \\
\hline $\begin{array}{l}\text { Averages } \\
\text { Index scores }\end{array}$ & 4.5 & $\begin{array}{l}3.0 \\
.7\end{array}$ & 8.5 & $\begin{array}{l}5.6 \\
1.3 \\
\end{array}$ & 2 & $\begin{array}{l}1.4 \\
.4\end{array}$ & 72 & $\begin{array}{l}47.6 \\
11.9 \\
\end{array}$ & 64.5 & $\begin{array}{l}42.6 \\
10.7\end{array}$ & 152 & 100 \\
\hline
\end{tabular}


The results show that majority $(94.7 \%)$ of the respondents agreed to having been provided with information on subject choice with 51.3 percent and 43.4 percent of the respondents agreeing (A) and strongly agreeing (SA) respectively. A minimal number $(0.7 \%)$ of the respondents were not sure (NS). Moreover, 2.6 percent of the respondents disagreed (D) that they are provided with information on subject choice while 2.0 percent strongly disagreed (SD) that they received information on subject choice. The implication of this is that majority of respondents receive information regarding subject choice in their schools. The significance of this information for this study is that availability of information on subject choice may influence decision making when choosing subjects to study in upper secondary schools-form three and four.

In this study, sufficiency of subject choice information was used to show that the information given to respondents is enough to influence their decisions by making them aware during decision making. More than half of the respondents $(84.5 \%)$ said that they receive sufficient subject choice information with 41.7 percent strongly agreeing (SA) and 43.8 percent agreeing (A). Only 2.0 percent of the respondents were not sure (NS).

However, 12.5 percent of the respondents said there is no sufficient subject choice information with $(8.6 \%)$ disagreeing (D) and (3.9\%) strongly disagreeing (SD). The implication of this is that majority of the respondents received enough subject choice information. Sufficiency of subject choice information was considered an important aspect of this study because it is important in creating awareness in the respondents when making subject choices due to the fact that they have several optional subjects to from which to choose.

It can be said therefore that information regarding subject choice is available and to a large extent with an index score of $22.6(11.9+10.7)$ out of the possible 25.0.

Githaiga (2011) noted that boys and girls faced some problems in their choice of Kenya Certificate of Secondary Education subjects. Such problems included lack of guidance, discouragement from friends and peers as well as difficulties in particular subjects.

\section{CONCLUSION}

From the results of this study, the following conclusions were drawn: i. Majority of students in secondary schools of uriri sub-county were found to be boys, girls were fewer.

ii. The information on subject choice was available for Agriculture students and is sufficient enough to help them in making decision. This information was available to a large extent. It can be said therefore that information on subject choice is sufficiently available to students in Uriri Sub-County.

\section{REFERENCES}

1. Quinter, M., \& Edwards, K. (2011). Factors influencing students career choices among secondary school students in Kisumu municipality, Kenya. Journal of emerging trends in educational research and policy studies, 2(2), 81-87.

2. Makori, E., Maobe, S., \& Nyangeri, J. (2019). Influence of Selected Factors on the Choice of Agriculture Subject among Secondary School Students in Kisii and Nyamira Counties. Asian Journal of Agricultural Extension, Economics \& Sociology, 1-12.

3. Gicharu, S. (2015). "Job satisfaction begins with the course you study after KCSE." The Standard, 15.

4. Hansel, S. (2009). "Agriculture enrolment grows across U.S: Job prospects attract students to major in Agriculture, " Retrieved November 23, 2012 from http://www.theaggie.org/article/2009/11 123

5. Migori County Director of Education. (2016). Inspection report for schools.

6. Ongang'a, P. O. (2016). Influence of selected school related and student related factors on the choice of agriculture subject among secondary school students in Uriri Sub-County, Kenya (Doctoral dissertation, Egerton University).

7. Kombo, D. K., \& Tromp, D. L. (2006). Proposal and thesis writing: An introduction. Nairobi: Paulines Publications Africa, 5, 814-30.

8. Kathuri, N. J., \& Pals, D. A. (1993). Introduction to education research. Education Media Centre, Egerton University.

9. Owoyele, J. W., \& Toyobo, O. M. (2008). Parental will, peer pressure, academic ability and school subject selection by students in Senior Secondary Schools. Ojebu-ode: Olubade Press, Ogun State, Nigeria.

10. Gathaiga, P. N. (2012). Factors influencing form two boys and girls choice of KCSE subjects in Kiene Division, Nyeri North District, Kenya (Doctoral dissertation, University of Nairobi, Kenya). 